\title{
Hubungan antara lingkar pinggang dengan kadar hematokrit pada pria dewasa muda
}

\author{
${ }^{1}$ Devinda Villarsi \\ ${ }^{2}$ Linda W. A. Rotty \\ ${ }^{2}$ Karel Pandelaki \\ ${ }^{2}$ Frans E. Wantania
}

\author{
${ }^{1}$ Kandidat Skripsi Fakultas Kedokteran Universitas Sam Ratulangi Manado \\ ${ }^{2}$ Bagian Ilmu Penyakit Dalam Fakultas Kedokteran Universitas Sam Ratulangi Manado \\ Email: devindavillarsi@gmail.com
}

\begin{abstract}
Central obesity plays an important role in the changes of blood circulation that can lead into several chronic diseases. The changes of blood circulation can be detected as earlier as possible by checking the hematocrit levels regularly. This study was aimed to determine the correlation between waist circumference and hematocrit levels in young adult males, This was a descriptive analytical study with a cross sectional design. Respondents were young adult males aged 20-28 years. This study was conducted from October 13 until November 11, 2016. Respondents were 38 young adult males consisting of 27 males with central obesity and 11 males without central obesity. The result of Spearman's rho analysis of the correlation between waist circumference and hematocrit level resulted in $r=0.156$ and $\mathrm{p}=0.350$. Conclusion: There was a weak positive correlation between waist circumference and hematocrit levels in young adult males but was not statistically significant.
\end{abstract}

Keywords: central obesity, hematocrit, young adult men.

\begin{abstract}
Abstrak: Obesitas sentral berperan penting terhadap terjadinya perubahan aliran darah dalam tubuh manusia yang selanjutnya dapat menimbulkan beberapa penyakit kronik. Perubahan aliran darah dapat dideteksi sedini mungkin dengan melakukan pemeriksaan kadar hematokrit secara teratur. Penelitian ini bertujuan untuk mengetahui hubungan antara lingkar pinggang dengan kadar hematokrit pada laki-laki dewasa muda. Jenis penelitian ialah deskriptif analitik dengan desain potong lintang. Responden penelitian ialah mahasiswa laki-laki berusia 20-28 tahun. Penelitian ini berlangsung dari tanggal 13 Oktober - 11 November 2016 dengan responden berjumlah 38 orang yang terdiri dari 27 mahasiwa obes sentral dan 11 mahasiswa non-obes sental. Hasil analisis uji Spearman's rho antara lingkar pinggang dengan kadar hemoglobin dari 38 responden diperoleh koefisien korelasi $r=0,134$ dengan nilai $p=0,422$. Simpulan: Terdapat hubungan positif lemah yang tidak bermakna antara lingkar perut dan hemoglobin.
\end{abstract}

Kata kunci: obesitas sentral, hematokrit, pria dewasa muda

Obesitas didefinisikan sebagai akumulasi lemak yang abnormal atau berlebihan yang dapat mengganggu kesehatan. Angka kejadian obesitas telah meningkat dengan pesat disemua kelompok umur, ras, jenis kelamin baik di negara maju maupun di negara berkembang. Menurut WHO (World Health Organization) pada tahun 2014, tercatat lebih dari 1,9 milyar orang dewasa overweight dan dari angka tersebut 600 juta orang yang mengalami obesitas. ${ }^{1,2}$

Menurut RISKESDAS tahun 2013, prevalensi obesitas penduduk Indonesia laki-laki dewasa (>18 tahun) pada tahun 2007 sebanyak 13,9\%, pada tahun 2010 sebanyak 7,8\% dan pada tahun 2013 
sebanyak $19,7 \%$ dengan prevalensi terendah di Nusa Tenggara Timur $(9,8 \%)$ dan tertinggi di provinsi Sulawesi Utara $(34,7 \%)$. Prevalensi obesitas pada perempuan dewasa ( $>18$ tahun) pada tahun 2007 sebanyak 13,9\%; pada tahun 2010 sebanyak 15,5\%; dan pada tahun 2013 sebanyak 32,9\% dengan prevalensi obesitas terendah di Nusa Tenggara Timur $(5,6 \%)$ dan prevalensi obesitas tertinggi di provinsi Sulawesi Utara (19,5\%). Data tersebut membuktikan bahwa prevalensi obesitas di Indonesia saat ini telah meningkat dengan pesat baik pada laki-laki maupun perempuan dan prevalensi obesitas tertinggi terdapat di Sulawesi Utara. ${ }^{3}$

Obesitas mempunyai peran penting terhadap terjadinya beberapa penyakit kronik; hal tersebut membuat angka morbiditas dan mortalitas pada orang obes meningkat. ${ }^{4,5}$ Pengukuran Indeks Massa Tubuh (IMT) merupakan cara yang paling sering dilakukan untuk menilai tingkatan obesitas dan memberikan gambaran total lemak di tubuh, tetapi beberapa studi mengungkapkan bahwa akumulasi lemak di sekitar abdomen (obesitas sentral) menyebabkan risiko lebih tinggi terhadap terjadinya penyakit sehingga pengukuran lingkar pinggang dianggap lebih akurat dalam menilai obesitas sentral. ${ }^{6}$

Pemeriksaan secara berkala pada obesitas sangat penting dilakukan sedini mungkin seperti pengukuran IMT dan pengukuran lingkar pinggang untuk menilai grade obesitas, serta pemeriksaan analisis darah yang merupakan suatu pemeriksaan penunjang untuk mendukung diagnosis dari suatu penyakit. Salah satu pemeriksaan yang penting dalam analisis darah yaitu analisis hematokrit yang merupakan persentase sel darah merah terhadap volume darah total. Pemeriksaan kadar hematokrit penting dilakukan karena setiap perubahan kadar hematokrit memberikan efek terhadap aliran darah, oleh karena itu pemeriksaan kadar hematokrit harus dikontrol secara rutin sebagai indeks dari berbagai keadaan fisiologik sehingga dapat mengurangi faktor risiko dari penyakit jantung. ${ }^{7} \quad$ Berdasarkan latar belakang tersebut, penulis terdorong untuk melakukan penelitian mengenai hubungan antara lingkar pinggang dan kadar hematokrit pada pria dewasa muda.

\section{METODE PENELITIAN}

Jenis penelitian ini ialah deskriptif analitik dengan desain potong lintang. Penelitian dilakukan di RSUP Prof. Dr. R. D. Kandou Manado dan di laboratorium Prokita untuk pemeriksaan analisis darah. Penelitian ini dilakukan pada tanggal 13 Oktober-11 November 2016.

Populasi penelitian ialah mahasiswa laki-laki Fakultas Kedokteran Universitas Sam Ratulangi Manado. Responden penelitian ialah mahasiswa laki-laki Fakultas Kedokteran Universitas Sam Ratulangi Manado yang sedang menjalani masa co-ass di RSUP Prof. Dr. R. D. Kandou Manado, diambil dengan menggunakan teknik consecutive sampling sebanyak 38 orang.

Kriteria inklusi sampel penelitian yaitu: Mahasiswa laki-laki Fakultas Kedokteran Universitas Sam Ratulangi Manado yang sedang menjalani masa coass di RSUP Prof. Dr. R. D. Kandou Manado dan sehat secara jasmani dan bersedia dijadikan responden (mengisi formulir informed consent). Kriteria eksklusi yaitu: kadar hemoglobin rendah (anemia) $<11,7 \mathrm{~g} / \mathrm{dl}$, sedang minum obat tertentu, dan perokok rutin.

Pengolahan data dilakukan dengan menggunakan program komputer SPSS dan disusun dalam bentuk tabel dan persentase. Analisis data yang digunakan yaitu uji korelasi.

\section{HASIL PENELITIAN}

Tabel 1 memperlihatkan karakteristik umum responden penelitian. Responden berusia 20-28 tahun, lingkar pinggang 70,4 $-128 \mathrm{~cm}$, kadar hematokrit 36,4\%-51,2\%, dan kadar hemoglobin 12,2g/dL-17,2g/dL.

Tabel 2 memperlihatkan distribusi responden berdasarkan lingkar pinggang, Jumlah responden obes sentral ialah 27 orang $(71,05 \%)$ dan yang non-obes sentral ialah 11 orang $(28,95 \%)$. 
Tabel 3 memperlihatkan karakteristik responden non-obes sentral yang berjumlah 11 mahasiswa berusia 21-24 tahun, lingkar pinggang 70,4-88 cm, kadar hematokrit $36,4-47,8 \%$ dan kadar hemoglobin 12,2$16,4 \mathrm{~g} / \mathrm{dL}$.

Tabel 4 memperlihatkan karakteristik sampel obesitas sentral yang berjumlah 27 mahasiswa. Usia subjek dari umur 20-28 tahun. Lingkar pinggang mulai dari $90 \mathrm{~cm}$ $128 \mathrm{~cm}$. Kadar hematokrit mulai dari $42,1 \%$ - 51,2\%. Kadar hemoglobin mulai dari $14,3 \mathrm{~g} / \mathrm{dL}-17,2 \mathrm{~g} / \mathrm{dL}$.

Tabel 1. Karakteristik umum responden penelitian

\begin{tabular}{lccccc}
\hline \multicolumn{1}{c}{ Variabel } & N & Min. & Max. & Mean & Std. Deviation \\
\hline Usia (tahun) & 38 & 20 & 24 & 22,86 & 1,69 \\
Lingkar pinggang (cm) & 38 & 70,4 & 128 & 96,19 & 11,96 \\
Hematokrit (\%) & 38 & 36,4 & 51,2 & 45,02 & 2,61 \\
Hemoglobin (g/dL) & 38 & 12,2 & 17,2 & 15,23 & 0,91 \\
\hline
\end{tabular}

Tabel 2. Distribusi responden berdasarkan lingkar pinggang

\begin{tabular}{lcc}
\hline & Frekuensi & \% \\
\hline Obesitas & 27 & 71,05 \\
Non-obesitas sentral & 11 & 28,95 \\
Total & 38 & 100 \\
\hline
\end{tabular}

Tabel 3. Karakteristik umum responden non-obes sentral

\begin{tabular}{lccccc}
\hline \multicolumn{1}{c}{ Variabel } & N & Min. & Max. & Mean & Std. Deviation \\
\hline Usia (tahun) & 11 & 21 & 24 & 22,36 & 1,02 \\
Lingkar pinggang (cm) & 11 & 70,4 & 88 & 82,30 & 5,17 \\
Hematokrit (\%) & 11 & 36,4 & 47,8 & 43,15 & 3,55 \\
Hemoglobin (g/dL) & 11 & 12,2 & 16,4 & 14,78 & 1,31 \\
\hline
\end{tabular}

Tabel 4. Karakteristik umum responden obes sentral

\begin{tabular}{lccccc}
\hline \multicolumn{1}{c}{ Variabel } & N & Min. & Max. & Mean & Std. Deviation \\
\hline Usia (tahun) & 27 & 20 & 28 & 23,07 & 1,88 \\
Lingkar pinggang (cm) & 27 & 90 & 128 & 101,85 & 8,86 \\
Hematokrit (\%) & 27 & 42,1 & 51,2 & 45,66 & 1,84 \\
Hemoglobin (g/dL) & 27 & 14,3 & 17,2 & 15,42 & 0,63 \\
\hline
\end{tabular}

Tabel 5 memperlihatkan hasil analisis uji Spearman's rho antara lingkar pinggang dengan kadar hematokrit dari total sampel sebanyak 38 orang mendapatkan koefisien korelasi $\mathrm{r}=0,156$ dengan nilai $\mathrm{p}=0,350$.

Tabel 5. Hasil uji korelasi Spearman's rho antara lingkar pinggang dengan kadar hematokrit

\begin{tabular}{lcc}
\hline Variabel & $\begin{array}{c}\text { Nilai koefisien } \\
\text { korelasi (r) }\end{array}$ & $\begin{array}{c}\text { Nilai } \\
\text { sig (p) }\end{array}$ \\
\hline $\begin{array}{l}\text { Lingkar perut- } \\
\text { hematokrit }\end{array}$ & 0,156 & 0,350 \\
\hline
\end{tabular}

Hal ini menyatakan terdapat hubungan positif lemah yang tidak bermakna antara lingkar perut dan hematokrit pada responden penelitian.

Tabel 6 memperlihatkan hasil analisis uji Spearman's rho antara lingkar pinggang dengan kadar hemoglobin dari total sampel sebanyak 38 orang mendapatkan koefisien korelasi $\mathrm{r}=0,134$ dengan nilai $\mathrm{p}=0,422$. Hal ini menyatakan terdapat hubungan positif lemah yang tidak bermakna antara lingkar perut dan hemoglobin pada responden penelitian. 
Tabel 6. Hasil uji korelasi Spearman's rho antara lingkar pinggang dengan kadar hemoglobin

\begin{tabular}{lcc}
\hline Variabel & $\begin{array}{c}\text { Nilai koefisien } \\
\text { korelasi (r) }\end{array}$ & $\begin{array}{l}\text { Nilai } \\
\text { sig (p) }\end{array}$ \\
\hline $\begin{array}{l}\text { Lingkar perut- } \\
\text { hemoglobin }\end{array}$ & 0,134 & 0,422 \\
\hline
\end{tabular}

\section{BAHASAN}

Penelitian ini menggunakan responden laki-laki dewasa muda karena laki-laki mempunyai tipe badan berbentuk seperti apple yang menandakan obesitas sentral yaitu distribusi lemak di sekitar abdomen, sedangkan perempuan mempunyai tipe badan berbentuk seperti pear dengan karakteristik akumulasi lemak pada bagian bawah tubuh. ${ }^{8,9}$ Obesitas sentral berkaitan dengan sejumlah penyakit, termasuk resistensi insulin, diabetes melitus tipe 2, kelebihan kadar lemak darah, tekanan darah tinggi, penyakit jantung koronaria, dan stroke. Orang dengan obesitas sentral memiliki proporsi lemak viseral lebih banyak, yang lebih mengkhawatirkan dibandingkan dengan lemak subkutan karena lemak viseral melepaskan lebih banyak adipokin proinflamasi yang memicu resistensi insulin dan inflmasi derajat rendah yang mendasari perkembangan aterosklerosis. ${ }^{10}$

Data yang diperoleh diuji normalitas dengan menggunakan uji Saphiro-Wilk karena sampel $<40$ dan didapatkan distribusi data lingkar perut normal $(\mathrm{p}=0,970)$, distribusi data kadar hematokrit tidak normal $(\mathrm{p}=0,007)$, dan distribusi data kadar hemoglobin tidak normal $(\mathrm{p}=0,019$. Pada ditribusi data yang tidak normal digunakan uji Spearman's rho.

Hasil uji Spearman's rho antara lingkar pinggang dengan kadar hematokrit pada laki-laki dewasa muda, didapatkan koefisien korelasi $r=0,156$, sedangkan hubungan lingkar pinggang dengan kadar hemoglobin didapatkan koefisien korelasi $\mathrm{r}$ $=0,134$ yang berarti bahwa terdapat hubungan positif lemah antara lingkar perut dengan kadar hematokrit dan terdapat hubungan positif lemah antara lingkar perut dengan kadar hemoglobin. Hasil penelitian Hämäläinen et al. ${ }^{11}$ menyatakan bahwa level eritropoietin meningkat secara bermakna pada orang dengan obesitas sentral. Eritropoietin merupakan hormon glikoprotein yang diproduksi oleh ginjal dan terstimulasi untuk dihasilkan bila terjadi keadaan hipoksia. ${ }^{12}$ Obesitas sentral dapat menyebabkan beberapa perubahan terhadap mekanisme pernapasan. Akumulasi dari lemak di sekitar dada, diaragma, dan perut akan mengurangi lebih dari $60 \%$ total pemenuhan sistem pernapasan sehingga menyebabkan hipoksia. ${ }^{13}$ Pengeluaran hormon eritropoietin pada gilirannya merangsang produksi eritrosit (eritropoesis) oleh sumsum tulang. ${ }^{14}$ Peningkatan aktivitas eritropoietik ini meningkatkan jumlah eritrosit dalam darah sehingga kapasitas darah mengangkut oksigen meningkat ${ }^{12}$ yang bila berlangsung terus menerus menyebabkan polisitemia sekunder yang ditandai dengan peningkatan kadar hemoglobin dan kadar hematokrit. ${ }^{15}$

Pada penelitian ini, hubungan antara lingkar pinggang dan kadar hematokrit mendapatkan $\mathrm{p}=0,350$ sedangkan hubungan antara lingkar pinggang dan hemoglobin mendapatkan $\mathrm{p}=0,422$ yang berarti tidak bermakna. Perubahan hematokrit dan hemoglobin tidak hanya terjadi pada orang dengan obesitas sentral, tetapi terdapat banyak faktor yang dapat memengaruhi. Salah satu dari faktor tersebut ialah adanya sindroma metabolic. Penelitian Hämäläinen et al. ${ }^{11}$ menyebutkan bahwa kadar hemoglobin lebih tinggi pada orang dengan sindroma metabolik. Hipoksia seluler yang terjadi pada orang dengan obesitas sentral dapat menyebabkan terjadinya resisten insulin dengan menghambat fosforilasi dari reseptor insulin sehingga menyebabkan penurunan transpor glukosa. ${ }^{16}$

Hubungan antara lingkar pinggang dan terjadinya sindroma metabolik sehingga meningkatkan kadar hemoglobin dan hematokrit juga dikemukakan dalam penelitian yang dilakukan oleh Vuong et al. ${ }^{17}$ Hal itu didukung juga dengan penelitian sebelumnya yang mendapatkan bahwa meskipun orang dengan obesitas 
sentral mengalami proses inflamasi yang dapat menekan proses eritropoiesis, tetapi eritropoiesis akan tetap meningkat pada sindroma metabolik sehingga terjadi peningkatan kadar hematokrit. ${ }^{18,19}$

Faktor lain yang juga dapat menyebabkan hasil uji statistik tidak bermakna ialah responden yang digunakan ialah laki-laki dewasa muda dengan rerata usia 22,64 tahun yang masih terbilang muda untuk terjadinya suatu perubahan terhadap komponen darah dan didapatkan bahwa kadar hematokrit dari semua sampel masih dalam batas normal. Hal ini berbeda dengan penelitian yang dilakukan oleh Vuong et al. ${ }^{17}$ yang menggunakan responden berusia 25-55 tahun dan mendapatkan hasil yang bermakna secara statistik.

\section{SIMPULAN}

Dari hasil penelitian dapat disimpulkan bahwa terdapat hubungan positif lemah antara lingkar pinggang dan kadar hematokrit pada laki-laki dewasa muda namun secara statistik tidak bermakna.

\section{SARAN}

Perlu dilakukan penelitian lebih lanjut mengenai hubungan antara lingkar pinggang dan kadar hematokrit pada lakilaki dewasa muda dengan jumlah responden lebih banyak dan cakupan lebih luas dengan mengikutsertakan gaya hidup serta lamanya mengalami obesitas.

\section{DAFTAR PUSTAKA}

1. World Health Organization. Obesity and overweight. June 2016.

2. Wang Y, Monteiro CA, Popkin BM. Trends of obesity and underweight in older children and adolescents in the United States, Brazil, China and Russia. Am J Clin Nutr. 2002;75(6): 971-7.

3. Badan Penelitian dan Pengembangan Kesehatan Kementerian Kesehatan Republik Indonesia. Riset kesehatan dasar 1 Desember 2013.

4. Zammit C, Liddicoat H, Moonsie I, Makker H. Obesity and respiratory disease. Int J General Med. 2010;3:335-43

5. Khurram M, Paracha SJ, Khar HTB,
Hasan Z. Obesity related complications in 100 obese subjects and their age matched controls. J Pak Med Assoc. 2006;56(2):50-3.

6. National Observatory Obesity. Measures of central adiposity as an indicator of obesity. August 2009.

7. Jedrzejewska-Szczerska M, Gnyba $M$. Optical investigation of hematocrit level in human blood. Acta Phys Pol A. 2011;120;642-46.

8. Després JP. Body fat distribution and risk of cardiovascular disease: an update. Circulation. 2012;126(10):1301-13.

9. Aucouturier J, Meyer M, Thivel D, TaillardatM, Duché P. Effect of android to gynoid fat ratio on insulin resistance in obese youth. Arch pediatr adolesc med. 2009;163(9): 826-31.

10. Sherwood L. Fisiologi Manusia dari Sel ke Sistem (8th ed). Jakarta: EGC, 2014; p. 684.

11. Hämäläinen $P$, Saltevo $J$, Kautiainen $H$, Mäntyselkä $\mathbf{P}$, Vanhala $\mathbf{M}$. Erythropoietin, ferritin, haptoglobin, hemoglobin, and transferrin receptor in metabolic syndrome: a case control study. Cardiovasc Diabetol. 2012;11: 116.

12. Jelkmann W. Erythropoietin: structure, control of production, and function. Physiol Rev. 1992;72(2):449-89.

13. Delisser HM, Grippi MA. Perioperative Respiratory Considerations. In: Fishman AP, Elias JA, Fishman JA, Grippi MA, Senior RM, Pack AI, editors. Fishman's Pulmonary Disease and Disorders (4th ed). United States: The McGraw-Hill Companies, 2008; . 668.

14. Sherwood L. Fisiologi manusia dari sel ke sistem (8th ed). Jakarta: EGC, 2014; p. 418-23.

15. McPherson RA, Pincus MR. Henry's Clinical Diagnosis and Management by Laboratory Methods (22nd ed). USA: Elsevier, 2011; p. 596.

16. Wood IS, de Heredia FP, Wang B, Trayhurn P. Cellular hypoxia and adipose tissue dysfunction in obesity. Proc Nutr Soc. 2009;68(4):370-77.

17. Vuong J, Qiu Y, La M, Clarke G, Swinkels DW, Cembrowski G. Reference intervals of complete blood count constituents are highly correlated to 
Villarsi, Rotty, Pandelaki, Wantania: Hubungan antara lingkar...

waist circumference: Should obese patients have their own "normal values?" Am. J. Hematol. 2014;89:671-77.

18. Barbieri M, Ragno E, Benvenuti $\mathrm{E}$, et al. New aspects of the insulin resistance syndrome: impact on haematological parameters. Diabetologia 2001;44: 1232-37.

19. Mardi T, Toker S, Melamed S, et al. Increased erythropoiesis and subclinical inflammation as part of the metabolic syndrome. Diabetes Res Clin Pract 2005;249-55. 